\title{
DINAMIK BAHASA MEDIA DALAM TALIAN: SUMBANGAN TERHADAP PERKAMUSAN MELAYU DI MALAYSIA
}

\author{
Wan Robiah MEOR OSMAN*1 \\ Wan Sofiah MEOR OSMAN² \\ ${ }^{1}$ Fakulti Bahasa dan Komunikasi,Universiti Malaysia Sarawak \\ ${ }^{2}$ Fakulti Sains Kognitif dan Pembangunan Manusia, Universiti Malaysia Sarawak \\ ${ }^{1}$ mowrobiah@unimas.my* \\ 2mowsofiah@unimas.my
}

Manuscript received 7 September 2020

Manuscript accepted 5 June 2021

*Corresponding author

https://doi.org/10.33736/ils.2546.2021

\begin{abstract}
ABSTRAK
Kemajuan teknologi maklumat berteraskan rangkaian jalur lebar antarabangsa telah mengubah komunikasi konvensional kepada komunikasi moden dalam talian. Komuniti dalam talian yang terdiri daripada pelbagai lapisan masyarakat tanpa mengira usia, gender, pendidikan dan status yang dilihat menggunakan bahasa dan menukar makna sesuatu kata dengan sewenang-wenangnya. Sesuatu kata yang digunakan oleh komuniti ini ada kalanya menjadi tular secara drastik dan meluas. Oleh itu, makalah ini meneliti kata-kata yang tular di media dalam talian dengan memanfaatkan Teori Tangan Ghaib oleh Keller (1994). Kajian ini juga menggunakan tiga buah kamus terpilih, iaitu A MalayEnglish Dictionary oleh Wilkinson (1901), Kamus Bahasa Melayu oleh Windstedt (1960), dan Kamus Dewan Edisi Keempat (2007) dalam memperlihatkan kepelbagaian makna menerusi masa dan enjin carian Google Trends untuk melihat trend carian popular netizen. Hasil kajian mendapati kesemua kata yang tular di media dalam talian berubah makna dan menyimpang daripada maksud asalnya di dalam kamus. Perubahan ini lazimnya disebabkan oleh perbezaan dalam sesebuah masyarakat daripada faktor sekeliling seperti sosioekonomi, sosiopolitik dan sebagainya. Oleh itu, kajian berkenaan perubahan bahasa masyarakat ini dapat menyumbang kepada pemerian makna baharu dalam kamus yang memberikan impak kepada pertambahan khazanah makna dalam kosa kata masyarakat dan menjadi pendokumentasian penting dalam memartabatkan bahasa negara bangsa.
\end{abstract}

Kata kunci: Bahasa dinamik; media dalam talian; perkamusan Melayu 


\title{
LANGUAGE DYNAMICS IN ONLINE MEDIA: THE ENRICHMENT OF MALAY LEXICOGRAPHY IN MALAYSIA
}

\begin{abstract}
The global internet network has prompted the transition of conventional communication to modern online communication. The online community which consists of people of varying social and economic backgrounds has commonly been observed to use language and modify the meaning of words freely. Some of these words may achieve extensive popularity online and become a viral sensation. Thus, the aim of this study was to examine Malay words that have become viral in online media using the Theory of Invisible Hand (Keller, 1994). Three selected dictionaries, namely, Wilkinson's (1901) A Malay-English Dictionary, Windstedt's (1960) Kamus Bahasa Melayu, and the Kamus Dewan Edisi Keempat (2007) were used to compare word meanings over time, while the Google Trend search engine was used to identify trends in popular online searches. The results showed that all the viral words in online media have changed in meaning from their original dictionary meanings. Among the common reasons for the changes in word meanings are the socioeconomic and socio-political changes occurring within the community. In sum, research on language change can facilitate the description of new dictionary meanings and play an important role in enriching the community's vocabulary repository, and documenting the ever-evolving language of the nation.
\end{abstract}

Keywords: Language dynamics; online media; Malay lexicography

\section{Pengenalan}

Kemodenan bersumberkan teknologi maklumat dalam masyarakat telah memberikan kesan terhadap gaya, bahasa dan budaya kehidupan. Bentuk komunikasi manusia misalnya sentiasa melalui perubahan hasil perkembangan teknologi atau revolusi komunikasi (Van Djik, dalam Siti Ezaleila Mustafa \& Azizah Hamzah, 2011).

Perkembangan teknologi maklumat dengan jumlah pengguna internet di dunia sebanyak 2,095 juta telah menjadikan ruang siber sebagai tempat menyatukan orang ramai yang saling berhubung dan membentuk kumpulan berdasarkan kepentingan dan minat masing-masing sehingga terbentuknya komuniti dalam talian. Komuniti ini memasuki ruang siber dengan pelbagai tujuan seperti mencari kawan, pendidikan, meluaskan jaringan perhubungan, mendapat sokongan dan sebagainya (Siti Ezaleila Mustafa dan Azizah Hamzah, dalam Wan Robiah Meor Osman \& Chong, 2019a). Komuniti ini terdiri daripada pelbagai lapisan masyarakat tanpa mengira usia, gender, pendidikan, status dan pekerjaan. Kumpulan ini dilihat menggunakan bahasa dan 
menukar makna sesuatu kata dengan sewenang-wenangnya berdasarkan konteks situasi semasa yang memberi impak kepada pola komunikasi dalam komuniti.

Kebiasaannya pola komunikasi yang terbentuk mempunyai ciri-ciri yang tersendiri mengikut kelompok komuniti yang disertai dan antara lain fungsi komunikasi kelompok adalah untuk hubungan sosial (Bungin, 2009). Pola komunikasi memperlihatkan proses interaksi yang berlaku antara individu dalam kelompok tertentu dengan tujuan menyampaikan mesej sehingga maksudnya boleh difahami (Djamarah, 2004). Sesuatu kata yang digunakan oleh mereka adakalanya menjadi tular secara drastik dan meluas. Komunikasi dalam talian yang bersifat perantaraan ini dilihat mulai popular dan mengambil tempat komunikasi berbentuk konvensional.

\section{Sorotan Kajian}

Bahasa media dalam talian bersifat dinamik kerana mengalami perubahan makna yang jauh menyimpang daripada makna asalnya di dalam kamus. Perubahan makna ini ketara digunakan dalam kalangan pengguna di media sosial seperti Facebook, Twitter dan Instagram. Terdapat tiga kajian yang diteliti oleh Wan Robiah Meor Osman dan Chong (2019a, 2019b, 2020) berkaitan kata-kata yang tular di media dalam talian ini. Menurut Wan Robiah Meor Osman dan Chong (2019a), perubahan makna yang berlaku dalam leksikal yang dikaji menunjukkan perubahan makna berlaku melangkaui makna asal yang terdapat di dalam kamus. Tiga kajian ini memanfaatkan Teori Tangan Ghaib oleh Keller (1994) terhadap sembilan kata terpilih, iaitu Lebai, Hadap, Hadam, Kafir, Meroyan, Kisah, Kunyit, Kencing dan Dedak. Hasil daripada ketiga-tiga kajian menunjukkan kesemua kata yang dikaji telah berubah makna secara drastik dalam penggunaannya oleh komuniti di media sosial Facebook dan portal berita Malaysiakini. Manakala perbandingan makna dalam dua kamus yang dipilih, iaitu Kamus Bahasa Melayu oleh Windstedt (1960) dan Kamus Dewan Edisi Keempat (2007) tidak menunjukkan perubahan makna yang signifikan walaupun kedua-dua buah kamus ini berbeza tahun terbitan hampir lima puluh tahun.

Alias Ismail (2018) menyatakan bahawa perkembangan komunikasi dalam talian telah memperlihatkan fenomena yang baharu dari aspek bentuk perhubungan dalam kalangan masyarakat. Media komunikasi baharu, iaitu media sosial didapati menyebabkan pengguna bahasa berkecenderungan mencipta makna baharu bagi kosa kata dan istilah yang tertentu, bergantung kepada skop dan konteks sesuatu komunikasi. Kajian ini memanfaatkan Teori Semantik Kognitif dalam menganalisis kata "Dedak". Hasil kajian mendapati bahawa leksikal "Dedak" misalnya tidak lagi tertakluk hanya kepada tiga takrif yang terdapat di dalam Kamus Dewan Edisi Keempat (2010), tetapi telah mewujudkan tiga peluasan makna bagi kata ini, iaitu upah, wang dan rasuah.

Kreativiti pengguna bahasa dalam memanipulasi sesuatu kata sehingga mewujudkan fenomena peluasan makna sering berlaku dalam kalangan netizen di media sosial. Peluasan makna ini akibat daripada perkembangan teknologi maklumat 
dan komunikasi yang sedang pesat berlaku. Nor Fazilah Noor Din (2016) turut bersetuju dengan menyatakan zaman teknologi telah mewujudkan pelbagai medium komunikasi baharu seperti Facebook, Twitter, Myspace dan Instagram yang secara tidak langsung telah menjadikan medium penggunaan bahasa semakin meluas. Pengguna media sosial dilihat terikut-ikut memanipulasi kata atau leksikal bahasa Melayu sehingga membentuk kata, istilah dan makna kata yang baharu. Nor Fazilah Noor Din (2016) telah meneliti kata "payung" di media sosial dengan menggunakan Teori Semantik Kognitif. Kajian yang bersumberkan data perisian WebCorp (437 kata) dan pangkalan data korpus Dewan Bahasa dan Pustaka (117 045 kata) ini mendapati bahawa kata "payung" telah mengalami peluasan makna, iaitu belanja, tunjuk, intai dan konsep pemasaran bersepadu.

Kedinamikan bahasa telah mewujudkan pelbagai istilah baharu dalam berbahasa masyarakat. Pengguna media dalam talian misalnya menggunakan istilahistilah baharu tertentu bagi tujuan menyampaikan mesej kepada pengguna bahasa sama ada mesej tersebut berbentuk positif mahupun negatif. Hishamudin Isam, Nor Fazilah Noor Din, Mashetoh Abd Mutalib, dan Sharifah Fazliyaton Shaik Ismail (2018) meneliti penggunaan kata "kekwat" dalam media sosial. Data diperoleh menerusi pangkalan data WebCorp dan dianalisis menggunakan perisian TextSTAT 2.9. Kajian ini memanfaatkan Teori Prosodi Semantik yang menganalisis kata dari segi pola penggunaan, analisis makna dan analisis nilai kata. Hasil kajian menunjukkan kata "kekwat" digunakan untuk merujuk lelaki atau perempuan yang berkelakuan sombong, membawa makna sombong dan digunakan dalam lingkungan pengaruh yang bersifat pejorasi. Ketiga-tiga analisis ini mendapati bahawa penggunaan kata ini sebagai kata yang kasar dan negatif.

Perubahan makna dalam perkamusan Melayu adalah sesuatu yang lazim kerana kamus bertujuan merekodkan bahasa masyarakat. Kamus merupakan salah satu dokumen penting dalam memperlihatkan gambaran sosial budaya dan ketamadunan sesuatu bangsa. Kajian Nazilah Mohamad, Karim Harun dan Nor Hasimah Ismail (2017) misalnya menyorot perubahan makna dan sosial budaya dalam perkamusan Melayu pada abad ke-19 dan abad ke-21. Kajian ini bertujuan memberikan gambaran tentang perubahan makna dalam dua zaman dan perubahan tersebut dibincangkan dari aspek linguistic (iaitu morfologi dan semantik) dan dari aspek luar linguistic (iaitu dari segi sosial dan sejarah). Kajian ini menganalisis dua kata, iaitu "jalang" dan "dendam" dengan menggunakan dua buah kamus berbeza zaman, iaitu Kamus Marsden (1812) dan Kamus Dewan Edisi Keempat (2013), di samping pangkalan data korpus Dewan Bahasa dan Pustaka. Hasil kajian menunjukkan kedua-dua kata ini menunjukkan perubahan makna dari segi peluasan makna bersifat peyorasi, iaitu makna positif bertukar kepada makna negatif. Faktor berlakunya penurunan makna ini disebabkan sejarah, peristiwa dan perubahan sosial budaya masyarakat. 


\section{Kaedah Kajian}

Kajian ini menggunakan kaedah kualitatif bersifat pensampelan bertujuan yang memanfaatkan laman Facebook dan Portal Berita dalam talian sebagai sumber data utama. Sebanyak empat kata yang tular dipilih, iaitu "bawang", "payung, "beliau" dan "kayangan". Populariti keempat-empat kata ini dilihat berdasarkan enjin carian Google Trends, iaitu satu enjin carian kata yang dibangunkan oleh syarikat Google bagi membolehkan pengguna dalam talian mencari kata menerusi kata kunci.

Perbandingan makna antara tiga buah kamus terpilih juga dilakukan terhadap keempat-empat kata ini. Kamus yang dipilih ialah A Malay-English Dictionary oleh Wilkinson (1901), Kamus Bahasa Melayu oleh Windstedt (1960) dan Kamus Dewan Edisi Keempat (2007). Ketiga-tiga kamus ini dipilih kerana ketiga-tiganya mempunyai tempoh terbitan antara 47 tahun hingga 59 tahun. Tempoh terbitan yang melebihi 40 tahun ini digunakan dalam memperlihatkan kepelbagaian makna dari segi perubahan sama ada dari segi peluasan, pengecilan atau penggantian.

Kesemua data kata ini memanfaatkan Teori Tangan Ghaib oleh Keller (1994) dalam memberikan gambaran tentang fenomena perubahan bahasa masyarakat dari segi keadaan ekologikal (ecological conditions), maksim tindakan (intentional actions), proses tangan ghaib (invisible hand process) dan pangkal penjelasan (explanandum). Keempat-empat aspek ini merupakan elemen utama yang digambarkan berdasarkan kerangka skema yang digunakan oleh Keller (1994) dalam menghuraikan atau memperjelas fenomena berbahasa dalam masyarakat (Rajah 1).

\section{Rajah 1}

Skema Teori Tangan Ghaib

Ecological Conditions

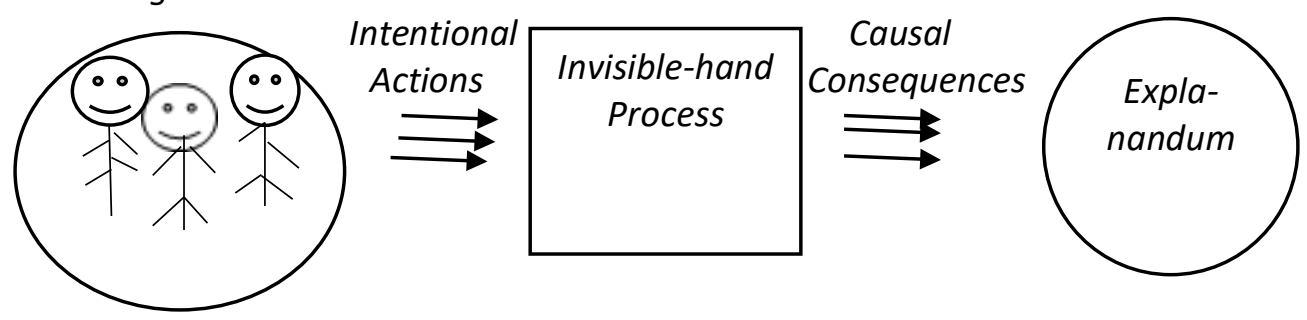

(a) Keadaan Ekologikal (Ecological Conditions)

Keadaan ekologikal ialah suatu fenomena berbahasa pada peringkat mikro yang melibatkan individu sebagai pelaku kepada perubahan bahasa. Pada peringkat ini penutur sebagai pengguna bahasa yang mempunyai latar belakang sosial yang rencam menggunakan sesuatu kata itu mengikut keperluan komunikasi semasa serta mempunyai niat terhadap sesuatu kata yang diujarkan. 
(b) Maksim Tindakan (Intentional Actions)

Maksim Tindakan merupakan suatu kecenderungan untuk bertindak mengikut cara tertentu atau sesuatu strategi perlakuan sama ada sedar atau tidak dalam fenomena perubahan bahasa. Maksim tindakan ini berfungsi sebagai pilihan terhadap sesuatu tindakan.

(c) Proses Tangan Ghaib (Invisible Hand Process)

Proses tangan ghaib ialah suatu proses luar kawalan manusia yang menerangkan proses perubahan makna dalam sesuatu kata. Proses perubahan makna dalam sesuatu kata itu berlaku secara tanpa sedar menerusi masa.

(d) Pangkal Penjelasan (Explanandum)

Pangkal penjelasan ialah suatu penyataan tentang kesan akibat sesuatu kata itu berubah makna (contohnya kehilangan sesuatu kata, peluasan dan perubahan makna dan sebagainya). Pada peringkat ini, hasil yang wujud (kehilangan kata, peluasan dan perubahan makna) adalah daripada pelbagai tindakan oleh individu.

Data daripada pensampelan bertujuan yang diperoleh akan dianalisis menggunakan skema dalam Teori Tangan Ghaib oleh Keller (1994) untuk memaparkan gambaran fenomena perubahan bahasa dalam masyarakat. Semua kaedah kutipan data dan analisis data dalam kajian ini dilihat berpada dalam usaha memperlihatkan fenomena berbahasa dalam kalangan masyarakat.

\section{Dapatan Dan Perbincangan}

Keempat-empat data yang dipilih dalam kajian ini merupakan kata-kata yang menjadi tular yang digunakan oleh masyarakat khususnya pengguna dalam talian di Facebook. Kata-kata ini akan dianalisis secara terperinci seperti berikut:

\section{Bawang}

Kata "bawang" dalam Kamus Bahasa Melayu oleh Windstedt (1960) dan Kamus Dewan Edisi Keempat (2007) mempunyai persamaan takrifan, iaitu merupakan sejenis tumbuhan yang mempunyai ciri-ciri kelopak berlapis, umbi yang dimakan, berbau keras dan rasanya sedap. Kedua-dua kamus ini kemudiannya memberikan penerangan tentang pelbagai jenis bawang. Dalam A Malay-English Dictionary oleh Wilkinson (1901) pula, kata "bawang" hanya diberikan terjemahan dalam bahasa Inggeris dan tidak diperjelaskan takrifan secara terperinci. Kamus ini juga menghuraikan pelbagai jenis bawang serta istilah kata "bawang" juga digunakan bukan sahaja untuk tumbuhan tetapi untuk jenis-jenis batu karang dan siput. Kamus Dewan Edisi Keempat (2007) kata "bawang" ini diberikan imbuhan yang menerbitkan kata kiasan marah dan kata ganda, 
iaitu bebawang. Berdasarkan penelitian dalam ketiga-tiga kamus ini didapati perubahan makna dalam kamus-kamus ini tidak menampakkan perubahan makna yang ketara walaupun tempoh terbitan ketiga-tiganya melebihi 40 tahun.

\section{Jadual 1}

Perbandingan Makna "Bawang" dalam Kamus

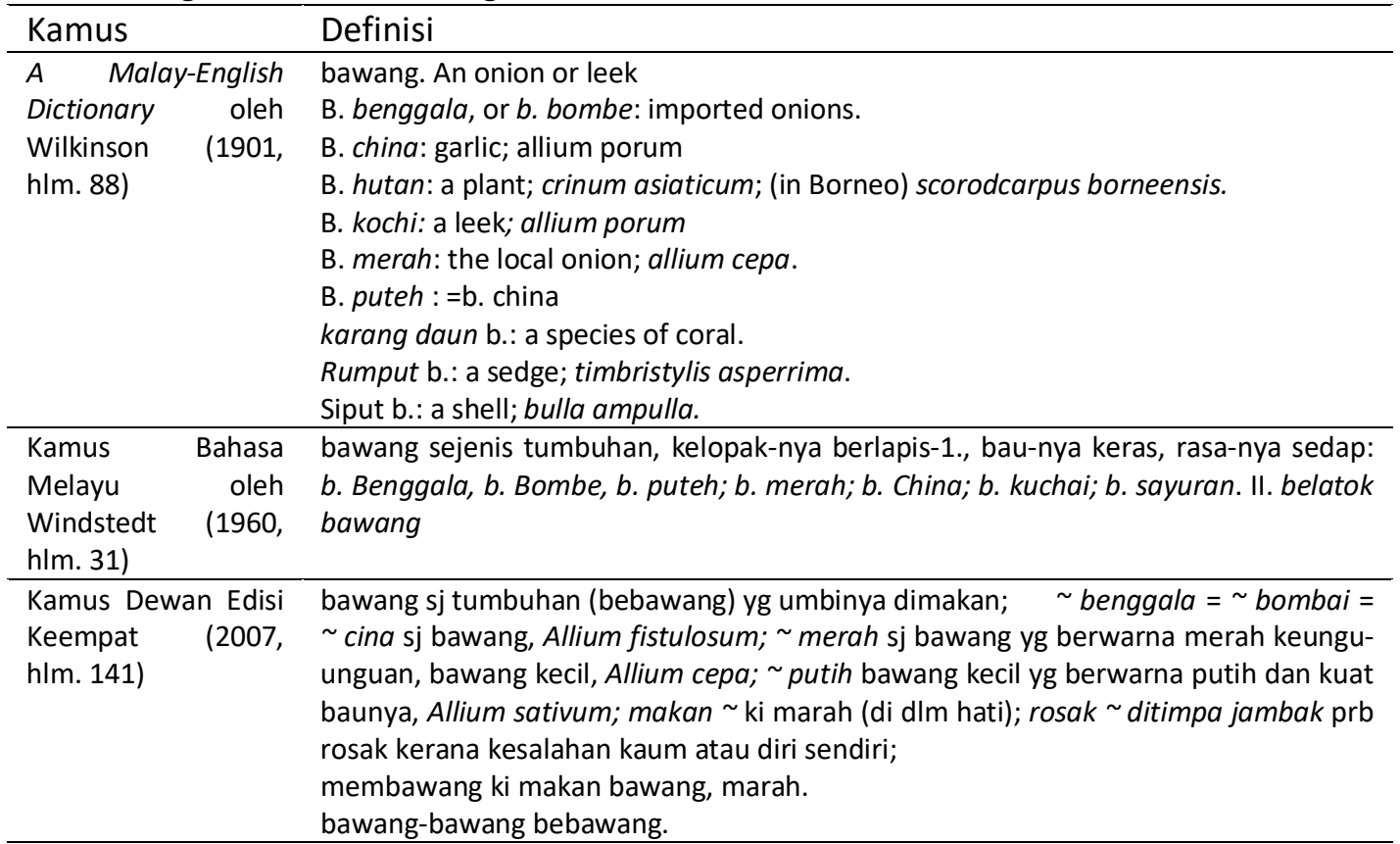

\section{Penggunaan Kata "Bawang" di Google Trends}

Dalam Google Trends pada Disember 2014 kata "bawang" digunakan hanya sebanyak 44\%. Kemudian meningkat naik secara berperingkat-peringkat hingga pada April 2018 melonjak penggunaannya $100 \%$ dan kemudian secara perlahan-lahan menurun sehingga Disember 2019 hanya digunakan sebanyak 53\% (Rajah 2). Carian kata "bawang" yang mencapai $100 \%$ menunjukkan kepopularan kata ini dalam kalangan pengguna di media dalam talian. 


\section{Rajah 2}

Penggunaan Kata Bawang di Google Trends

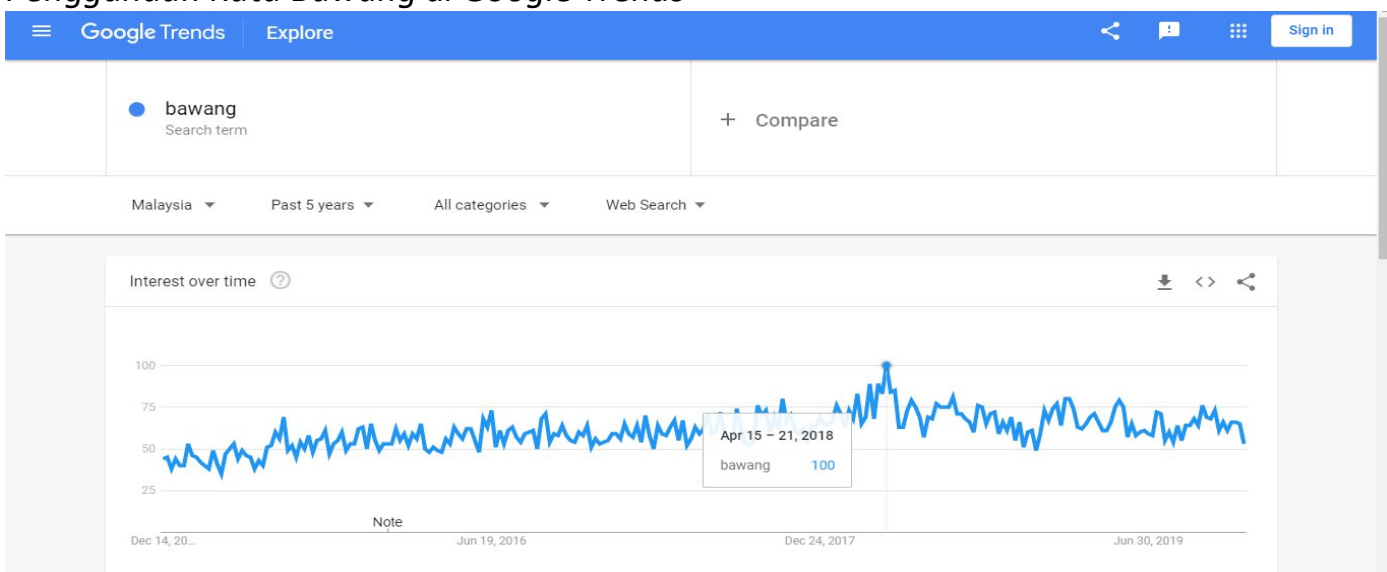

\section{Penggunaan Kata "Bawang" di Media Dalam Talian}

Kata "bawang" dan "membawang" didapati banyak digunakan oleh pengguna dalam talian. Jadual 2 menunjukkan contoh penggunaannya:

\section{Jadual 2}

Data 1: Penggunaan Kata "Bawang" dan "Membawang" di Media Dalam Talian

\begin{tabular}{|c|c|c|}
\hline Kata & Makna & Contoh Ayat \\
\hline \multirow[t]{5}{*}{$\begin{array}{c}\text { Bawang } \\
\text { II }\end{array}$} & Gosip/bergosip & $\begin{array}{l}\text { (1) Kelab Bawang Jutawan - sambil membawang jadi } \\
\text { jutawan } \\
\text { https://www.facebook.com/groups/358447637989379/) }\end{array}$ \\
\hline & $\begin{array}{l}\text { Mengumpat/ } \\
\text { bergosip }\end{array}$ & $\begin{array}{l}\text { (2) Menjalo pagi2 lebih bagus dari membawang, } \\
\text { alhamdulillah sempat molah pakei minum pagi walaupun } \\
\text { belum berapo } \quad \text { nk jadi } \\
\text { https://www.facebook.com/salbiahassan) }\end{array}$ \\
\hline & $\begin{array}{l}\text { Mengumpat/ } \\
\text { bergosip }\end{array}$ & $\begin{array}{l}\text { (3) Beruntung nasib badan...wanita yang comel adalah } \\
\text { wanita yang pandai membawa wang bukan pandai } \\
\text { membawang } \\
\text { https://www.facebook.com/alfianyusop) }\end{array}$ \\
\hline & $\begin{array}{l}\text { Mengumpat/ } \\
\text { bergosip }\end{array}$ & $\begin{array}{l}\text { (4) Kalau nak membawang pun janganlah sampai } \\
\text { memfitnah } \\
\text { orang..hurm } \\
\text { (sumber:https://www.facebook.com/coret4anhati) }\end{array}$ \\
\hline & $\begin{array}{l}\text { Bercerita, } \\
\text { berbual, } \\
\text { bergosip }\end{array}$ & $\begin{array}{l}\text { (5) Bila Mak - Anak memBAWANG Hahahahaha Ada saja } \\
\text { Breaking News! Padahal, hari2 kot membawang!! } \\
\text { Hahaha Sungguh aku bersyukur dgn AnugerahNya } \\
\text { (sumber: https://www.facebook.com/hafizhashim) }\end{array}$ \\
\hline
\end{tabular}


Berdasarkan penelitian contoh-contoh ayat yang digunakan oleh pengguna media sosial kata "bawang" dan "membawang" telah mengalami peluasan makna. Hal ini boleh dilihat makna dalam tiga kamus yang diteliti tidak mempunyai persamaan makna dengan perbualan oleh pengguna siber. Perbualan dalam Facebook didapati makna kata "bawang" dan "membawang" telah melangkaui makna asal dalam kamus yang mentakrifkan "bawang" ialah sejenis tumbuhan dan "membawang" pula ialah kata kiasan makan bawang atau marah. Kata-kata ini dilihat berubah makna, iaitu "gossip", "bergosip", "mengumpat", "bercerita" dan "berbual" berdasarkan konteks setiap ayat yang diperturunkan di atas. Jika diteliti rata-rata pengguna media sosial Facebook menggunakan kata "bawang" atau "membawang" ini untuk perbuatan yang negatif berbanding positif.

\section{Payung}

Berdasarkan analisis takrifan dalam ketiga-tiga kamus di bawah adalah sama, iaitu "payung" ialah sejenis alat pelindung yang lazimnya diperbuat daripada kain atau kertas yang digunakan untuk melindungi seseorang daripada panas atau hujan. Alat ini juga digunakan untuk pelbagai tujuan sama ada sebagai alat kebesaran dalam majlis diraja dan dalam ketenteraan (payung terjun). Pelbagai jenis payung dinyatakan dalam ketigatiga kamus ini seperti contoh yang diperturunkan dalam Jadual 3. Menerusi analisis menunjukkan bahawa pemerian makna dalam ketiga-tiga kamus ini tidak menunjukkan suatu perubahan makna yang signifikan. Ketiga-tiganya dilihat mempunyai pemerian makna yang hampir sama, cuma dalam Kamus Dewan Edisi Keempat (2007) terdapat makna baharu bagi kata "payung", iaitu sejenis tumbuhan.

\section{Jadual 3}

Perbandingan Makna "Payung" dalam Kamus

\begin{tabular}{|c|c|c|}
\hline \multicolumn{2}{|l|}{ Kamus } & Definisi \\
\hline \multicolumn{2}{|c|}{ A Malay-English } & payong. An umbrella, a parasol, a sun-shade; shelter under an umbrella; (by \\
\hline & oleh & extension) the head of a nail. \\
\hline \multirow{9}{*}{$\begin{array}{l}\text { Wilkinson } \\
\text { hlm. 452) }\end{array}$} & $(1901$, & P. ubor-ubor: a state umbrella with a heavy fringe; Ht. Bakth., 14. \\
\hline & & $\begin{array}{l}\text { P. berapit: two small umbrellas borne side by side in the train of a prince; Sej. Mal., } \\
93,122 \text {. }\end{array}$ \\
\hline & & P. bawat: a (Javanese) state umbrella; Ht. Mas, Ed. \\
\hline & & P. chetera: a sort of canopy or fringed umbrella; Sh. Bur. Nuri, 30. \\
\hline & & Payongkan: to shelter under an umbrella; Ht. Sh. Kub. Memayongkan: id; Ht. Ind. \\
\hline & & \\
\hline & & $\begin{array}{l}\text { The umbrella being an appurtenance of Malay royalty, the word payong is used, by a } \\
\text { complimentary metaphor, to signify "king" or "lord." }\end{array}$ \\
\hline & & Banyak muda sudah ku banding, \\
\hline & & $\begin{array}{l}\text { Tuwan sa-orang payong negeri: many youths have I compared (with you), but you } \\
\text { alone are king of this place (my heart). }\end{array}$ \\
\hline Kamus & Bahasa & payong alat pelindung, jangan terkena panas atau hujan; payong ubor-u., p. iram-i. \\
\hline Melayu & oleh & payong kebesaran raja, p.berjurai, p. beropol di-tepi; $p$. terbang, $p$. alat payong akan \\
\hline $\begin{array}{l}\text { Windstedt } \\
\mathrm{h} / \mathrm{m} .223)\end{array}$ & $(1960$ & $\begin{array}{l}\text { membawa orang turun dari kapal terbang; } p \text {. negeri pelindung negeri, tempat } \\
\text { bernaung; payong paku kepala paku; berpayong }(\mathrm{a}) \text { berpakai payong, (b) berpayong }\end{array}$ \\
\hline
\end{tabular}


terbang, (t) berupa payong (ia-lah awan); memayongkan, memayongi melindongkan, menaungkan.

Kamus Dewan Edisi payung I 1. alat bertangkai yg biasanya dibuat drpd kain, kertas, dsb yg dipasang pd

Keempat (2007, kerangka boleh lipat utk melindungi seseorang atau sesuatu drpd terkena hujan

hlm. 1154) atau panas matahari dan juga digunakan sbg alat kebesaran raja dll; kain; kertas; sutera; paku paku yg kembang kepalanya dan digunakan utk memaku atap zink; 2. $=\sim$ terjun kain bulat yg diberi bertali pd tepinya dan digunakan utk terjun dr kapal terbang (tempat tinggi dll); askar terjun pasukan askar yg digugurkan oleh kapal terbang; 3. ki sesuatu yg melindungi, penaung, pelindung: pd suatu ketika dahulu Tanah Melayu berlindung di bawah Inggeris;

$\sim$ bawat $=\sim$ pawat Jw payung kecil yg berbatang tinggi dan berwarna-warni (utk menunjukkan kebesaran seseorang); berapit payung kerajaan yg dibawa berdampingan di hadapan raja dll; cetera sj payung utk menunjukkan kebesaran seseorang; iram-iram = rama-rama sj payung kuning yg bahagian tepinya berlipat-lipat dan terumbai-umbai (utk raja-raja); perteduhan naungan ki tempat berteduh, tempat bernaung, tempat mempertaruhkan nasib; ubur-ubur sj payung putih yg berlipat-lipat tepinya utk memayungkan jenazah raja (di setengah-setengah tempat digunakan juga oleh raja yg masih hidup);

dianjungkan spt , diambak spt kasur prb terlalu sangat dimuliakan atau dihormati (terutama orang besar-besar); sediakan sebelum hujan prb hendaklah bersiap sedia sebelum terjadi sesuatu yg kurang baik;

payung II; ali a) sj tumbuhan (herba), Biophytum adiantoides; b) sj tumbuhan (pokok), Eurycoma longifolia; daun sj tumbuhan (palma), daun keruh, daun lat, daun sang, daun sar, daun segaluh, daun selebar, Teysmannia altifrons; rumput $\sim \mathrm{sj}$ tumbuhan (rumpai),

\section{Penggunaan Kata "Payung" di Google Trends}

Kata "payung" dalam Google Trends menunjukkan kata ini konsisten menjadi carian pengguna media dalam talian. Menerusi Rajah 3 di bawah kata payung pada Disember 2014 hanya digunakan sebanyak 18\% sahaja. Jika dilihat dalam rajah 3 ini kata payung mencapai 100\% penggunaannya pada Februari 2016 dan kemudian menurun secara konsisten dan naik semula pada Oktober 2017 sebanyak 73\%. Kata ini dilihat menjadi popular secara tiba-tiba dan kemudian menurun kembali. Fenomena ini merupakan suatu keadaan yang biasa berlaku kepada mana-mana kata yang tular. Lazimnya katakata yang tular ini akan mendadak digunakan oleh masyarakat dalam suatu tempoh tertentu kemudian lama-kelamaan kata ini mulai menghilang atau kurang digunakan. Hal yang sama juga berlaku kepada kata "payung" ini. 


\section{Rajah 3}

Penggunaan Kata "Payung" di Google Trends
$\equiv$ Google Trends Explore
$<\quad: \because:$ signin

Malaysia - Past 5 years $>\quad$ All categories $~ W \quad$ Web Search

Interest over time

$\pm\langle\prec$

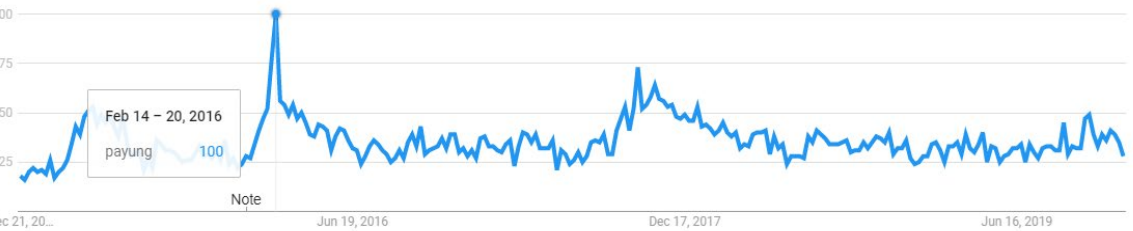

\section{Penggunaan Kata "Payung" di Media Dalam Talian}

Kata "payung" dilihat sering digunakan oleh pengguna dalam talian. Dalam Jadual 4 diperturunkan beberapa contoh penggunaan kata ini.

\section{Jadual 4}

Data 2: Penggunaan Kata "Payung" di Media Dalam Talian

\begin{tabular}{|c|c|c|}
\hline Kata & Makna & Contoh Ayat \\
\hline Payung III & Berkongsi & $\begin{array}{l}\text { (1)JANGAN CAKAP BABU X PAYUNG K... } \\
\text { hahahhaha...gambar dorang jakk yang banyak dlm } \\
\text { phone... Terutamanya abg ilham n adek hana } \\
\text { maisarah.. (sumber: } \\
\text { https://www.facebook.com/banunbini) }\end{array}$ \\
\hline \multirow[t]{3}{*}{ Payung IV } & Belanja & $\begin{array}{l}\text { (2) Tq atas ingatan \& payung kami na... Moga terus } \\
\text { berjaya pd ms depan. Jaga diri tatkala belayar di lautan } \\
\text { nanti, ingat Allah selalu \& masak sedap2 na...(sumber: } \\
\text { https://www.facebook.com/roniibrahim) }\end{array}$ \\
\hline & Belanja & $\begin{array}{l}\text { (3) Dah lama x bersiaran... rezeki jgn ditolak Tq tok } \\
\text { Nafizal Haris payung. Tahniah dan Selamat berglittering } \\
\text { semua } \\
\text { https://www.facebook.com/engkuafiz) }\end{array}$ \\
\hline & Belanja & $\begin{array}{lll}\text { (4) Berbuka dengan kengkawan AW...YB Komander } \\
\text { payung } & \text { kali } & \text { ni...(sumber: } \\
\text { https://www.facebook.com/engkuafiz) }\end{array}$ \\
\hline Payung V & Tolong/Bantu & (5) Jangan cakap abang tak payung \\
\hline
\end{tabular}


(sumber:https//www.facebook.com/msmo)

Kata "payung" menerusi konteks penggunaannya dalam kelima-lima contoh di atas menunjukkan kata ini telah berubah makna daripada makna asalnya yang terdapat di dalam ketiga-tiga kamus yang diteliti. Kata "payung" ini berubah makna menghasilkan tiga peluasan makna, iaitu berkongsi, belanja dan tolong atau bantu. Berkongsi dalam konteks ayat di atas bermaksud menunjukkan gambar bagi tujuan untuk dilihat bersama-sama dengan rakan-rakan atau sharing dalam bahasa Inggeris. Belanja pula bermaksud memperuntukkan sejumlah wang kepada orang lain bagi merapatkan atau meningkatkan sesuatu hubungan sosial. Dalam ketiga-tiga konteks ayat di atas kata belanja digunakan untuk makanan. Manakala kata "payung" yang bermaksud tolong atau bantu pula lebih menjurus kepada perbuatan atau jasa yang dibuat kepada seseorang.

\section{Beliau}

Kata ganti nama diri (KGND) "beliau" sangat menarik untuk dikaji kerana menerusi makna dalam ketiga-tiga kamus yang diteliti tiada perubahan makna yang ketara (Jadual 5). Dalam A Malay-English Dictionary oleh Wilkinson (1901) dan Kamus Bahasa Melayu oleh Windstedt (1960) maknanya hampir sama, iaitu gelaran atau panggilan kepada seseorang atau binatang yang namanya tidak mahu disebut kerana mempunyai unsur ditakuti. Dalam Kamus Bahasa Melayu oleh Windstedt (1960) makna ketiganya digunakan untuk orang tua atau orang yang dihormati. Makna ini sama dalam Kamus Dewan Edisi Keempat (2007) dan ia merupakan KGND ketiga. Walaupun ketiga-tiga kamus ini berbeza tahun terbitannya melebihi 40 tahun, namun didapati perubahan maknanya tidak menunjukkan perbezaan yang ketara. Perkara yang menarik bagi KGND ketiga ini ialah penggunaannya di media dalam talian yang mempunyai perubahan makna yang ketara.

\section{Jadual 5}

Perbandingan Makna "Beliau" dalam Kamus

\begin{tabular}{|c|c|}
\hline Kamus & Definisi \\
\hline $\begin{array}{l}\text { A Malay-English } \\
\text { Dictionary oleh } \\
\text { Wilkinson (1901, hlm. } \\
\text { 115) }\end{array}$ & $\begin{array}{l}\text { beliau An appellation given to persons whom one does not wish to name for fear } \\
\text { of the name attracting attention to what is being said, - e.g. when one is speaking } \\
\text { of a tiger in the jungle or of a prince in his own dominions. }\end{array}$ \\
\hline $\begin{array}{lr}\text { Kamus } & \text { Bahasa } \\
\text { Melayu } & \text { oleh } \\
\text { Windstedt } & (1960, \\
\text { hlm. 35) } & \\
\end{array}$ & $\begin{array}{l}\text { beliau (1) orang yang tersebut tadi, iaitu. (2) anu, folan, di-pakai pada orang mati } \\
\text { atau binatang yang ditakuti. (3) In., ia, di-pakai pada orang tua dan orang yang di- } \\
\text { hormati. }\end{array}$ \\
\hline $\begin{array}{l}\text { Kamus Dewan Edisi } \\
\text { Keempat }(2007, \mathrm{hlm} \text {. } \\
\text { 155-156) }\end{array}$ & seorang pendiam, tidak suka anak-anaknya terlampau banyak bercakap. \\
\hline
\end{tabular}




\section{Penggunaan Kata "Beliau" di Google Trends}

Kata "beliau" digunakan dalam kadar yang rendah sejak Disember 2014, iaitu sebanyak 28\%. Kata ini turun dan naik secara konsisten digunakan di media dalam talian, walaupun demikian pada April 2018 kata ini telah melonjak naik penggunaannya ke $100 \%$. Trend berbahasa bagi kata ini dilihat dipengaruhi oleh suasana sekeliling terutamanya yang berkaitan dengan sosiopolitik negara. Kata ini menjadi popular secara mendadak dan tiba-tiba. Menerusi Rajah 5 didapati pada Disember 2019 kata ini mulai meningkat semula ke $78 \%$.

\section{Rajah 5}

Penggunaan Kata "Beliau" di Google Trends

\section{$\equiv$ GoogleTrends Explore $\quad<\quad$ : :i: Signin}
- beliau
Malaysia - Past 5 years $~ A l l c$ categories - Web Search -
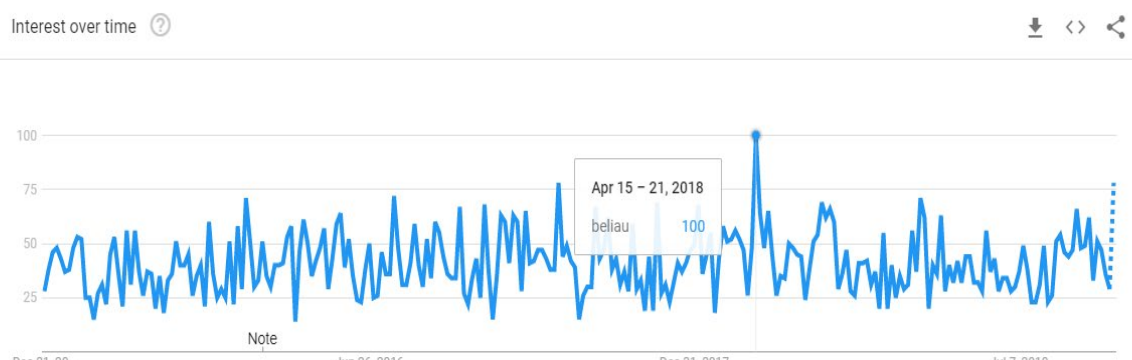

\section{Penggunaan Kata "Beliau" di Media Dalam Talian}

Penggunaan kata "beliau" dalam talian didapati mempunyai perubahan makna daripada makna asalnya di dalam ketiga-tiga kamus yang diteliti. Jadual 6 menunjukkan contoh penggunaan kata "beliau": 


\section{Jadual 6}

Data 3: Penggunaan Kata "Beliau" di Media Dalam Talian

\begin{tabular}{|c|c|c|}
\hline Kata & Makna & Contoh Ayat \\
\hline \multirow[t]{5}{*}{$\begin{array}{l}\text { Beliau } \\
\text { II }\end{array}$} & \multirow{5}{*}{$\begin{array}{l}\text { KGND/kata } \\
\text { panggilan } \\
\text { negatif }\end{array}$} & $\begin{array}{l}\text { (1) Lagi Nampak Bodoh Sangat-Sangat YB Beliau. } \\
\text { (sumber:https://www.facebook.com/page.idris.haron/) }\end{array}$ \\
\hline & & $\begin{array}{l}\text { (2) Dengar sebut 'gari' je, beliau terus tanya pasal kafe, lepas } \\
\text { tu tanya pula ruang menunggu. KAH KAH KAH. Ini balai polis } \\
\text { la YB, nak minum2, menunggu orang, pergi mall la. (sumber: } \\
\text { https://www.facebook.com/tenteratrollkebangsaanmalaysia) }\end{array}$ \\
\hline & & $\begin{array}{l}\text { (3) Oiiii yaibe babisss beliau ko dh servis van ko ke musibat } x \\
\text { lama Ig ko jd pembangkang pulak... Ko tgu le...Baruah punya } \\
\text { beliau. (sumber: https//www.facebook.com/shafiqsapet) }\end{array}$ \\
\hline & & $\begin{array}{l}\text { (4) Mcm mane lak beliau nk jd pembangkang...next pru die } \\
\text { kalah weh....Hahahhahahahahha...jd tauke babi beliau itu } \\
\text { (https://www.facebook.com/aaamran) }\end{array}$ \\
\hline & & $\begin{array}{l}\text { (5) Elok la ko tag yb beliau ni, biar belajar siket bahasa } \\
\text { melayu, ade ke binatang pnggil beliau. } \\
\text { (sumber: https://www.facebook.com/fizi) }\end{array}$ \\
\hline
\end{tabular}

Dalam konteks pengguna media sosial didapati bahawa KGND beliau yang bersifat positif dalam Kamus Bahasa Melayu oleh Windstedt (1960) dan Kamus Dewan Edisi Keempat (2007) telah berubah menjadi negatif. Hal ini sangat menarik untuk diteliti kerana KGND atau kata panggilan ini kesemuanya ditujukan kepada wakil rakyat yang bergelar Yang Berhormat (YB). Kebanyakan kata ini digunakan secara negatif dalam bentuk cacian dan makian.

\section{Kayangan}

Istilah "kayangan" yang digabungkan bersama-sama kata kluster ini sangat menarik untuk diteliti kerana ia merupakan istilah baharu yang wujud dalam masyarakat disebabkan oleh situasi semasa akibat pandemik koronavirus (COVID-19). Penelitian makna bagi ketiga-tiga kamus menunjukkan istilah ini merupakan istilah yang tidak begitu produktif. Contohnya, dalam A Malay-English Dictionary oleh Wilkinson (1901) "kayangan" mempunyai tiga makna, iaitu berkaitan ketuhanan, ekspresi merasakan sesuatu yang menarik serta luar biasa yang bersifat positif dan gelaran yang digunakan terhadap perempuan daripada keluarga atau golongan terhormat (Jadual 7). Manakala dalam Kamus Bahasa Melayu oleh Windstedt (1960) dan Kamus Dewan Edisi Keempat (2007) pula mempunyai maksud yang sama, iaitu tempat dewa-dewa atau syurga. Perbandingan makna dalam ketiga-tiga kamus ini tidak mempunyai perubahan makna yang ketara walaupun tempoh ketiga-tiga kamus ini diterbitkan melebihi 40 tahun. 
Jadual 7

Perbandingan Makna "Kayangan" dalam Kamus

\begin{tabular}{ll}
\hline Kamus & Definisi \\
\hline A Malay-English & keyangan. See yang (divinity) \\
Dictionary oleh & yang \\
Wilkinson (1901, hlm. & I. Divinity: Godhead. Sembah-yang: to pray to God; to pray; v. sembahyang. \\
$552 / 697)$ & II. An expression having the force of a relative, bringing the word or clause \\
& following it into relation with that which precedes; e.g., masa yang baik: a fortune \\
& time, a lucky moment. \\
& III. a title used in addressing ladies of respectable family: an abbreviation of \\
& dayang, q.v.
\end{tabular}

\begin{tabular}{lr}
\hline $\begin{array}{l}\text { Kamus Bahasa Melayu } \\
\text { oleh Windstedt (1960, }\end{array}$ & keyangan tempat Yang, shurga (sa-belum orang berugama Hindu) \\
hlm. 158) & \\
\hline $\begin{array}{l}\text { Kamus Dewan Edisi } \\
\text { Keempat (2007, hlm. }\end{array}$ & $\begin{array}{r}\text { yang II = yang-yang dewa; } \\
\text { beryang-yang membaca mantera memanggil dewa-dewa, memuja }\end{array}$ \\
& dewa-dewa: maka tuan puteri pun mengambil gaharu cendana. \\
\hline
\end{tabular}

\section{Penggunaan Kata "Kayangan" dan Kluster "Kayangan" di Google Trends}

Penelitian menerusi Google Trends menunjukkan dalam Rajah 6 kata "kayangan" digunakan secara konsisten turun dan naik tidak melebihi 50\% sejak tahun 2016. Kata ini hanya melonjak dengan ketara pada April 2020 semasa negara khususnya dan dunia amnya sedang menghadapi lonjakan jumlah yang dijangkiti koronavirus (COVID-19). Penelitian enjin carian ini menunjukkan penggunaan yang ketara kata ini oleh masyarakat umum khususnya di Malaysia.

\section{Rajah 6}

Penggunaan Kata "Kayangan" di Google Trends

\section{$\equiv$ Google Trends Explore}

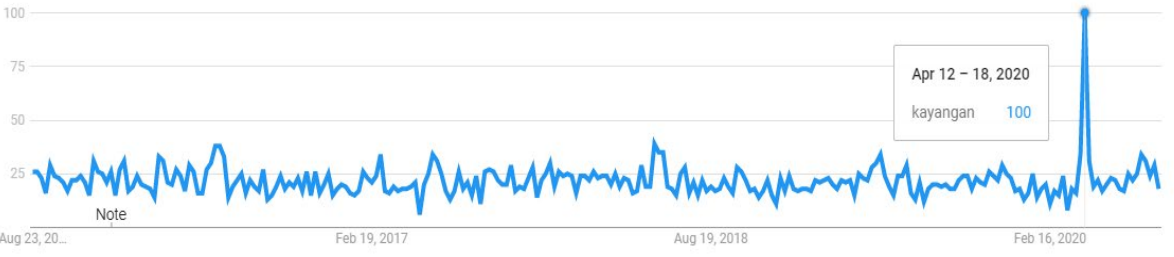


Manakala dalam Rajah 7 pula, pengkaji cuba meneliti carian Google Trends bagi kluster kayangan pula menunjukkan bahawa kata ini tidak digunakan sejak 2016 dengan mencatat $0 \%$ penggunaan. Frasa ini hanya ketara digunakan pada April 2020 dan kemudian mengalami turun naik dalam kadar kurang 25\%. Hal ini menunjukkan pengguna dalam talian telah menggunakan kata ini dengan drastik pada April 2020 akibat situasi pandemik koronavirus (COVID-19) yang berlaku di seluruh dunia. Istilah ini secara tiba-tiba menjadi popular dan digunakan oleh masyarakat umum dan penulis akhbar dalam talian.

\section{Rajah 7}

Penggunaan Kata Kluster "Kayangan" di Google Trends

$\equiv$ Google Trends Explore

kluster kayangan Search term

Malaysia - Past 5 years $>$ All categories $>$ Web Search $\checkmark$

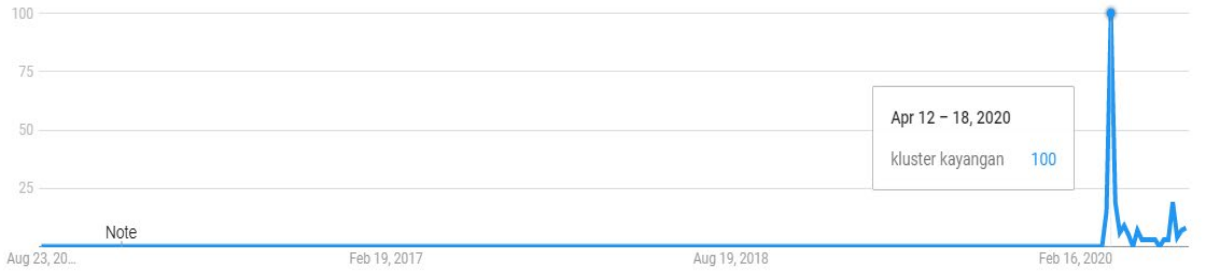

\section{Penggunaan Kata Kayangan di Media Dalam Talian}

Situasi semasa dunia yang sedang menghadapi pandemik Koronavirus (COVID-19), iaitu sejenis virus yang telah menjangkiti manusia telah mewujudkan istilah baharu dalam perbualan masyarakat. Istilah kluster "kayangan" mulai digunakan oleh masyarakat secara drastik sejak April 2020 disebabkan berlakunya situasi, iaitu rakyat Malaysia yang kebanyakannya berkhidmat di luar negara telah kembali ke Malaysia dan menjalani kuarantin selama 14 hari. Golongan ini telah digelar oleh masyarakat umum sebagai kluster atau kelompok "kayangan" disebabkan oleh tuntutan layanan kelas pertama yang diminta daripada pihak hospital dan pihak yang menyediakan kemudahan penginapan mereka serta pelbagai kerenah yang wujud daripada golongan ini. Jadual 8 menunjukkan contoh penggunaan kata "kayangan" di media dalam talian. 
Jadual 8

Data 4: Penggunaan Kata "Kayangan" di Media Dalam Talian

\begin{tabular}{|c|c|c|}
\hline Kata & Makna & Contoh Ayat \\
\hline \multirow[t]{5}{*}{ Kayangan II } & $\begin{array}{l}\text { berharta/ } \\
\text { kaya/ternama/ } \\
\text { terhormat }\end{array}$ & $\begin{array}{l}\text { (1) "Kelab kayangan" langgar PKPP } \\
\text { (sumber:https://www.bharian.com.my/berita/nasio } \\
\text { nal/2020/07/ 715251) }\end{array}$ \\
\hline & & 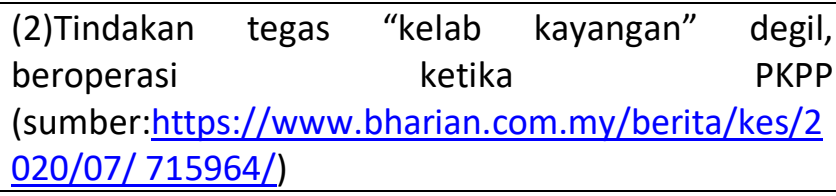 \\
\hline & & $\begin{array}{l}\text { (3)COVID-19 tidak peduli jika anda kluster kayangan, } \\
\text { sila patuh PKP - Ismail Sabri (sumber: } \\
\text { http://www.astroawani.com/berita-malaysia/covid- } \\
\text { 19) }\end{array}$ \\
\hline & & $\begin{array}{l}\text { (4)Diminta beri jawapan jujur hal VIP beraya langgar } \\
\text { SOP, Ismail serah polis siasat - "Kluster kayangan } \\
\text { atau bumi sama sahaja" (sumber: } \\
\text { https://www.mstar.com.my/lokal/semasa/2020/05/ } \\
27 /)\end{array}$ \\
\hline & & $\begin{array}{l}\text { (5)Jika kerajaan terus bertegas mengarahkan kluster } \\
\text { kayangan ini menjalani kuarantin wajib di pusat } \\
\text { kuarantin sejak mula lagi, pasti kita masih kekal } \\
\text { dengan } 1 \text { angka kes atau sifar kes pada hari ini. } \\
\text { (sumber: https://www.facebook.com/TENTERAKITA) }\end{array}$ \\
\hline
\end{tabular}

Menerusi dapatan data 4, dapat dilihat contoh penggunaan kata "kayangan" digunakan secara meluas dalam kalangan pengguna siber. Dalam makalah ini hanya diperturunkan beberapa contoh sahaja. Bukan sahaja kluster "kayangan" kerap digunakan tetapi kata "kayangan" ini digandingkan dengan kata-kata lain seperti golongan atau kelab. Kesan daripada penggunaan kata "kayangan" ini dalam talian menunjukkan kata ini telah berubah makna daripada maksud asal dalam kamus menjadi makna baharu, iaitu ditujukan khusus untuk kelompok atasan yang mempunyai kedudukan dari segi harta, pangkat dan status. Oleh sebab itu, masyarakat menggelarkan golongan ini sebagai kelompok atau kluster "kayangan".

\section{Perubahan Makna dalam Skema Teori Tangan Ghaib}

Berdasarkan perubahan makna dalam konteks ayat oleh pengguna media sosial dapatlah dirumuskan perubahan makna ini menerusi Skema Teori Tangan Ghaib. Analisis perubahan makna dapat dilihat daripada keempat-empat kata yang diteliti (Jadual 10). 
Pada tahap keadaan ekologikal dalam Skema Teori Tangan Ghaib Keller (1994) kata "bawang" yang asalnya bermaksud sejenis tumbuhan yang mempunyai ciri-ciri kelopak berlapis, umbi yang dimakan, berbau keras dan rasanya sedap, telah berubah makna menerusi maksim tindakan (menyindir), iaitu tanpa sedar pengguna telah mengubah makna dan kelas kata (Kata Nama-Kata Nama (KN-KN)/Kata Kerja (KK)). Proses perubahan ini dapat diteliti dalam kelima-lima contoh yang diperturunkan, iaitu contoh "membawang" (1) hingga (5) membawa bermaksud yang hampir sama, iaitu bercerita, berbual bergosip dan mengumpat. Konteks "membawang" dalam contohcontoh ini lebih menjurus kepada bercerita, berbual, bergosip tentang sesuatu yang hangat diperkatakan sehingga adakalanya dapat dikategorikan sebagai mengumpat.

Bagi kata "bawang" dalam contoh (1), iaitu "Kelab Bawang Jutawan" juga memberikan gambaran yang negatif, walaupun slogannya berunsur positif, iaitu "sambil membawang boleh jadi jutawan". Slogan ini seolah-olah menunjukkan bahawa kelab ini walaupun bergosip tetapi boleh menjana pendapatan sehingga menjadi jutawan. Gambaran negatif ini juga dipersetujui oleh Wan Norasikin Wan Ismail dan Nurul Najihah Jamal (2019) yang mengatakan bahawa kata "membawang" ini mempunyai konotasi budaya yang negatif dan bersinonim dengan bahasa kiasan seperti membawa mulut, suka menjaga tepi kain orang dan mesyuarat tingkap. Jika diteliti, makna "membawang" dalam Kamus Dewan Edisi Keempat (2007) berupa kata kiasan bagi makan bawang dan marah. Kedua-dua makna bagi kata kiasan ini didapati tidak digunakan oleh pengguna dalam talian yang diteliti.

Dalam Proses Tangan Ghaib, kelas kata "bawang" yang asalnya kata nama apabila menjadi "membawang" telah bertukar kepada kata kerja. Oleh hal yang demikian, daripada penggunaan yang tinggi bagi kata "bawang" dan "membawang" dalam talian, maka ia telah memberikan kesan akibat bagi kata ini yang pada pangkal penjelasan kata ini telah mengalami peluasan makna, iaitu bercerita, berbual, bergosip dan mengumpat. Perubahan ini adalah daripada kesan penggunaan bahasa oleh pengguna dalam talian yang secara kolektif telah mengubah makna kata ini tanpa disedari.

Seterusnya, bagi kata "payung" pula dalam Skema Teori Tangan Ghaib Keller (1994) pada peringkat ekologikal pengguna bahasa secara sedar mengetahui makna asal kata ini, tetapi telah menggunakannya bagi maksud yang baharu. Dalam contoh (2) hingga (4) kata "payung" membawa maksud belanja, iaitu wang yang dikeluarkan untuk memberikan ganjaran kepada seseorang dalam bentuk makanan. Bagi contoh (1) pula kata "payung" bermaksud seseorang "belanja gambar" atau "berkongsi gambar", iaitu seseorang individu yang banyak mengambil gambar anak-anak buahnya untuk tatapan umum. Konsep mengambil gambar ini menyamai konsep belanja tetapi dalam bentuk berkongsi dan bukan dalam bentuk wang.

Selain itu, kata "payung" dalam konteks ayat (5) mempunyai maksud membantu atau menolong. Bantuan atau pertolongan ini bukan berbentuk wang namun lebih menjurus kepada perbuatan atau jasa seseorang. Oleh itu, melalui maksim tindakan (menyampaikan mesej) dapat dilihat Proses Tangan Ghaib berlaku yang menyebabkan 
kata ini tanpa kawalan telah tular digunakan oleh pengguna dalam talian. Hal ini telah menyebabkan perubahan kelas kata daripada kata nama (KN) kepada kata kerja (KK). Hal yang sama juga berlaku terhadap perubahan maknanya daripada sejenis alat untuk melindungi panas dan hujan kepada kata yang menunjukkan kata kerja berkongsi, belanja atau membantu. Pada peringkat pangkal penjelasan, iaitu kesan akibat daripada perubahan kelas kata dan makna dalam interaksi sosial masyarakat menyebabkan kata "payung" telah mengalami peluasan makna.

\begin{tabular}{|c|c|c|c|c|}
\hline \multicolumn{5}{|l|}{$\begin{array}{l}\text { Jadual } 10 \\
\text { Skema Teori Tan }\end{array}$} \\
\hline Keadaan Ekologikal & \multicolumn{2}{|c|}{ Proses Tangan Ghaib } & \multicolumn{2}{|c|}{ Pangkal Penjelasan } \\
\hline $\begin{array}{c}\text { Bawang } \\
\text { Sejenis tumbuhan }\end{array}$ & $\begin{array}{l}\text { Maksim } \\
\text { Tindakan }\end{array}$ & KN-KN/KK & $\begin{array}{c}\text { Kesan - } \\
\text { Akibat }\end{array}$ & $\begin{array}{c}\text { bercerita, berbual, } \\
\text { bergosip, } \\
\text { mengumpat }\end{array}$ \\
\hline $\begin{array}{c}\text { Payung } \\
\text { Sejenis alat untuk } \\
\text { melindungi panas } \\
\text { dan hujan }\end{array}$ & $\begin{array}{c}\stackrel{\longrightarrow}{\longrightarrow} \\
\begin{array}{c}\longrightarrow \text { menyampaikan } \\
\text { menej/ }\end{array} \\
\text { mencaindir/ }\end{array}$ & KN-KK & $\begin{array}{c}\longrightarrow \\
\text { (Peluasan } \\
\text { makna/ } \\
\text { Perubahan } \\
\text { makna) }\end{array}$ & $\begin{array}{c}\text { berkongsi, belanja } \\
\text { (wang, benda lain), } \\
\text { membantu/ } \\
\text { menolong }\end{array}$ \\
\hline $\begin{array}{c}\text { Beliau } \\
\text { KGND ketiga (utk } \\
\text { org tua dan orang } \\
\text { yang dihormati) }\end{array}$ & & $\begin{array}{c}\text { KGND } \\
\text { (positif) - } \\
\text { KGND } \\
\text { (negatif) }\end{array}$ & & $\begin{array}{l}\text { KGND ketiga (utk } \\
\text { orang yang disindir/ } \\
\text { dicaci) }\end{array}$ \\
\hline $\begin{array}{c}\text { Kayangan } \\
\text { Tempat dewa- } \\
\text { dewa/ketuhanan/ } \\
\text { syurga/ ekspresi } \\
\text { kata positif/kata } \\
\text { panggilan }\end{array}$ & & KN-KA & & $\begin{array}{c}\text { berharta/ } \\
\text { kaya/berkedudukan } \\
\text { ternama/ } \\
\text { terhormat }\end{array}$ \\
\hline
\end{tabular}

Sementara itu, bagi kata "beliau" pula didapati bahawa pada peringkat ekologikal yang merupakan fenomena berbahasa yang melibatkan individu sebagai pelaku kepada perubahan bahasa menunjukkan kata "beliau" yang maksud asalnya dalam kamus adalah positif KGND ketiga dan panggilan kepada orang tua atau orang yang dihormati) telah menjadi negatif. Menariknya, KGND ketiga atau kata panggilan yang positif ini telah bertukar kepada negatif kesan daripada penggunaan di media sosial Facebook yang telah menjadikan kata ini sebagai sindiran atau kiasan. Sindiran atau kiasan ini ditujukan kepada individu sama ada mempunyai jawatan politik atau 
tidak yang dianggap bodoh atau bebal. Kata ini juga dilihat digunakan bersama-sama jawatan, iaitu YB (Yang Berhormat). Kebanyakan pengguna menggunakan YB Beliau seperti contoh (1). Kesemua contoh kata "beliau" ini menunjukkan makna negatif bagi KGND ini.

Kesan daripada penggunaan ini menyebabkan pada peringkat maksim tindakan yang merupakan strategi perlakuan pengguna dengan secara sedar telah menggunakan kata "beliau" bagi tujuan menyindir tanpa berselindung kepada pihak yang disasarkan mesej sindiran ini. Oleh itu, dalam Proses Tangan Ghaib kata ini telah berubah makna namun kelas kata masih sama, iaitu KGND atau kata panggilan. Pada peringkat pangkal penjelasan yang merupakan kesan akibat sesuatu kata itu telah mengalami peluasan makna menjadi KGND orang ketiga atau kata panggilan yang disindir atau dicaci ekoran kebodohan atau kebebalannya (dari sudut pandangan pengguna dalam talian) berkenaan sesuatu isu yang berkaitan dengan politik semasa.

Data terakhir, iaitu kata "kayangan" pula, pada tahap keadaan ekologikal dalam Skema Teori Tangan Ghaib Keller (1994) menunjukkan kata ini yang asalnya bermaksud tempat dewa-dewa, syurga, berkaitan hal ketuhanan, ekspresi kata positif dan kata panggilan kepada perempuan daripada keluarga ternama telah berubah makna menerusi maksim tindakan (menyindir), iaitu tanpa sedar pengguna telah mengubah makna dan kelas kata Kata Nama (KN) menjadi Kata Adjektif (KA) yang membawa maksud kaya, berharta, ternama, terhormat. Proses perubahan ini dapat diteliti dalam kelima-lima contoh yang diperturunkan, iaitu contoh (1) hingga (2) membawa bermaksud ternama atau terhormat manakala contoh (3) hingga (5) membawa maksud kaya, berharta dan berkedudukan. Menariknya, kata "kayangan" itu sendiri yang menunjukkan tempat yang istimewa yang mempunyai kedudukan yang teratas dijadikan kiasan oleh pengguna dalam talian terhadap golongan yang mempunyai harta, pangkat dan status. Kreativiti pengguna dalam talian dalam mengaitkan sesuatu kata itu menunjukkan cerminan pemikiran yang kreatif dan tinggi.

Justeru, menerusi analisis ini dapat dilihat perubahan makna dalam pertuturan pengguna siber berlaku secara drastik. Pada peringkat awalnya pengguna bahasa yang mempunyai latar belakang yang rencam dari segi usia, gender, pendidikan, status dan pekerjaan telah menggunakan sesuatu kata dengan niat tertentu. Menerusi niat ini mewujudkan maksim tindakan seperti sindiran, cacian, ejekan dan sebagainya yang menjadi sebab musabab sesuatu tindakan berlaku dalam mengubah sesuatu makna kata. Daripada situasi ini, telah mewujudkan proses tangan ghaib, iaitu suatu proses di luar kawalan manusia yang tanpa sedar telah mengubah makna atau kelas kata yang akhirnya menimbulkan kesan akibat sesuatu kata itu berubah makna contohnya kehilangan kata, peluasan makna, penyempitan makna dan sebagainya. Oleh hal yang demikian, perubahan makna dalam komunikasi pengguna di media sosial merupakan suatu proses tanpa kawalan dan tanpa sedar ia berlaku secara tiba-tiba dan bersifat drastik. Sesuatu kata boleh secara tiba-tiba menjadi viral dan popular digunakan dan menerusi masa kata-kata ini secara perlahan-lahan hilang daripada perbualan pengguna siber. Hal ini juga dipersetujui oleh Wan Robiah Meor Osman dan Chong (2019a) yang 
mengatakan perubahan sesuatu kata boleh berlaku secara evolusi (perlahan-lahan dan mengambil masa yang lama) atau revolusi (perubahan secara mendadak dan tiba-tiba) untuk menjadi popular dalam kalangan masyarakat.

\section{Kesimpulan}

Berdasarkan keempat-empat data yang dikaji didapati bahawa wujud perubahan makna yang drastik penggunaannya di media dalam talian. Perubahan makna ini melangkaui makna asal yang terkandung di dalam ketiga-tiga kamus yang telah diteliti. Perubahan makna ini memberikan kesan besar kepada perkamusan Melayu. Kedinamikan bahasa dalam talian ini merupakan suatu perkembangan yang positif dalam bidang leksikografi. Seharusnya pihak yang berkaitan leksikografi perlu memastikan semua makna yang berubah ini direkodkan dan dimasukkan ke dalam kamus. Hal ini penting bagi memastikan perkamusan Melayu khususnya kekal relevan kepada masyarakat pengguna. Pihak Dewan Bahasa dan Pustaka khasnya perlu merangka dan mencadangkan satu alternatif yang bersifat mudah, pantas dan terkini seperti e-kamus bagi merekodkan semua makna kata-kata yang telah berubah ini. Alternatif ini penting dalam memastikan bahasa Melayu khususnya boleh terus berkembang pesat dan kekal relevan dalam era globalisasi berteraskan teknologi maklumat.

\section{Penghargaan}

Makalah ini merupakan hasil daripada Geran MyRA F09/SpMYRA/1664/2018. Penghargaan ditujukan khas kepada pihak UNIMAS atas pembiayaan Geran MyRA ini. Penghargaan juga kepada Prof. Madya Dr. Chong Shin (UKM) kerana perkongsian maklumat berkaitan teori dan leksikografi dalam makalah ini. 


\section{Rujukan}

Alias Ismail. (2018). Peluasan makna kata dedak: Satu analisis semantik kognitif. International Journal of Education, Psychology and Counseling, 3(10), 28-39.

Bungin, B. (2009). Sosiologi komunikasi: Teori, paradigma, dan diskursi teknologi komunikasi di masyarakat. Jakarta: Kencana.

Djamarah, B. S. (2004). Pola komunikasi orang tua \& anak dalam keluarga. Jakarta: PT. Reneka Cipta.

Hishamudin Isam, Nor Fazilah Noor Din, Mashetoh Abd Mutalib, \& Sharifah Fazliyaton Shaik Ismail. (2018). Kekwat: Di mana bahasa dan akal budi bangsa kita? Jurnal Linguistik, 22(1), 001-017.

Kamus Dewan Edisi Keempat. (2007). Kuala Lumpur: Dewan Bahasa dan Pustaka.

Keller, R. (1994). The invisible hand in language. London: Routledge.

Nazilah Mohamad, Karim Harun, \& Nor Hasimah Ismail. (2017). Perubahan makna dan sosial budaya dalam masa 200 tahun: Penelitian terhadap perkamusan Melayu. Pertanika Journal, 4(1), 49-62.

Nor Fazilah Noor Din. (2016). Peluasan makna payung dalam kalangan pengguna bahasa Melayu berdasarkan analisis semantik kognitif. Proceedings of International Seminar on Generating Knowledge Through Research (ICECRS), 779-810.

Siti Ezaleila Mustafa, \& Azizah Hamzah. (2011). Media baharu yang baharu: Trend penggunaan jaringan sosial dalam kalangan pengguna di Malaysia. Jurnal Pengajian Media Malaysia, 13(2), 93-110.

Wan Norasikin Wan Ismail, \& Nurul Najihah Jamal. (2019). Bawang dan membawang. Retrieved from http://klikweb.dbp.my/wordpress/?p=14325

Wan Robiah Meor Osman, \& Chong, S. (2019a). Revolusi bahasa dalam media sosial penyumbang perkamusan Melayu. Prosiding Seminar Antarabangsa Pendidikan Bahasa, Sastera dan Budaya Melayu Kedua (SAPBaSBUM), 458-474.

Wan Robiah Meor Osman, \& Chong, S. (2019b). Fenomena evolusi dan revolusi makna perkataan Melayu: Tinjauan awal. Asian Journal of Environment, History and Heritage, 13(2), 195-210.

Wan Robiah Meor Osman, \& Chong, S. (2020). Perubahan makna leksikal "dedak" di media dalam talian: Sumbangan kepada perkamusan Melayu. International Journal of the Malay World and Civilisation, 8(1), 37-46.

Wilkinson, R. J. (1901). A Malay-English Dictionary. Singapore: Kelly \& Walsh Limited.

Windstedt, R. O. (1960). Kamus bahasa Melayu. Kuala Lumpur, Malaysia: Marican \& Sons (Malaysia) Sdn. Berhad. 